\title{
NBSIR 76-1153
}

\section{Microstructural Aspects of Deformation and Oxidation of Magnesia-Doped Silicon Nitride}

N. J. Tighe

Inorganic Materials Division

Institute for Materials Research

National Bureau of Standards

Washington, D. C. 20234

September 1976

Interim Report for Period 1 July, 1976 to September 30, 1976

Prepared for

United States Air Force

Air Force Systems Command Aeronautical Systems Division

Wright Patterson Air Force Base, Ohio 45433 



\section{MICROSTRUCTURAL ASPECTS OF DEFORMATION AND OXIDATION OF MAGNESIA-DOPED SILICON NITRIDE}

N. J. Tighe

Inorganic Materials Division Institute for Materials Research National Bureau of Standards

Washington, D. C. 20234

September 1976

Interim Report for Period 1 July, 1976 to September 30, 1976

Prepared for

United States Air Force

Air Force Systems Command

Aeronautical Systems Division

Wright Patterson Air Force Base, Ohio 45433

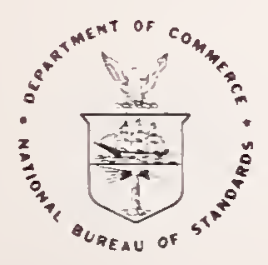

U.S. DEPARTMENT OF COMMERCE, Elliot L. Richardson, Secretary Edward O. Vetter, Under Secretary

Dr. Betsy Ancker-Johnson, Assistant Secretary for Science and Technology

NATIONAL BUREAU OF STANDARDS, Ernest Ambler, Acting Director 

MICROSTRUCTURAL ASPECTS OF DEFORMATION AND OXIDATION OF MAGNESIA DOPED SILICON NITRIDE*

N. J. Tighe

Institute for Materials Research, National Bureau of Standards, Washington, D. C. 20234

ABSTRACT. The microstructural changes that occurred in magnesiadoped silicon nitride as a result of slow crack growth, plastic deformation and oxidation were studied by transmission electron microscopy. Specimens which exhibited slow crack growth showed extensive crack branching along the fracture path and ahead of the primary crack tip. These primary and secondary cracks followed intergranular paths. In samples which were deformed by bending at $1400^{\circ} \mathrm{C}$, dislocation arrays were found as well as intergranular cracks and voids. Silicon nitride oxidized during heating in air at $1400^{\circ} \mathrm{C}$ and enstatite and cristobalite were present in the oxide layer. At lower oxidation temperatures, crystalline and amorphous silica formed a semiprotective layer on the silicon nitride surfaces.

\section{Introduction}

Silicon nitride compacts have heterogeneous microstructures because the grains vary in morphology and in phase. Grain sizes within some compacts range from a few tenths to several micrometers in diameter. The sintered grain phases are $\alpha$-silicon nitride, $\beta$-silicon nitride and silicon carbide, and there are large inclusions of silicon oxy-nitride and tungsten silicide. The tungsten particles are picked up during the grinding of the powder prior to compaction.

It is necessary to use electron microscopy to study the morphology and structure of individual grains in fine-grained silicon nitride compacts. This method requires special techniques that are not available in all laboratories, and microstructural

* Presented at NATO-ASI Institute Canterbury, England August 15-27, 1976 

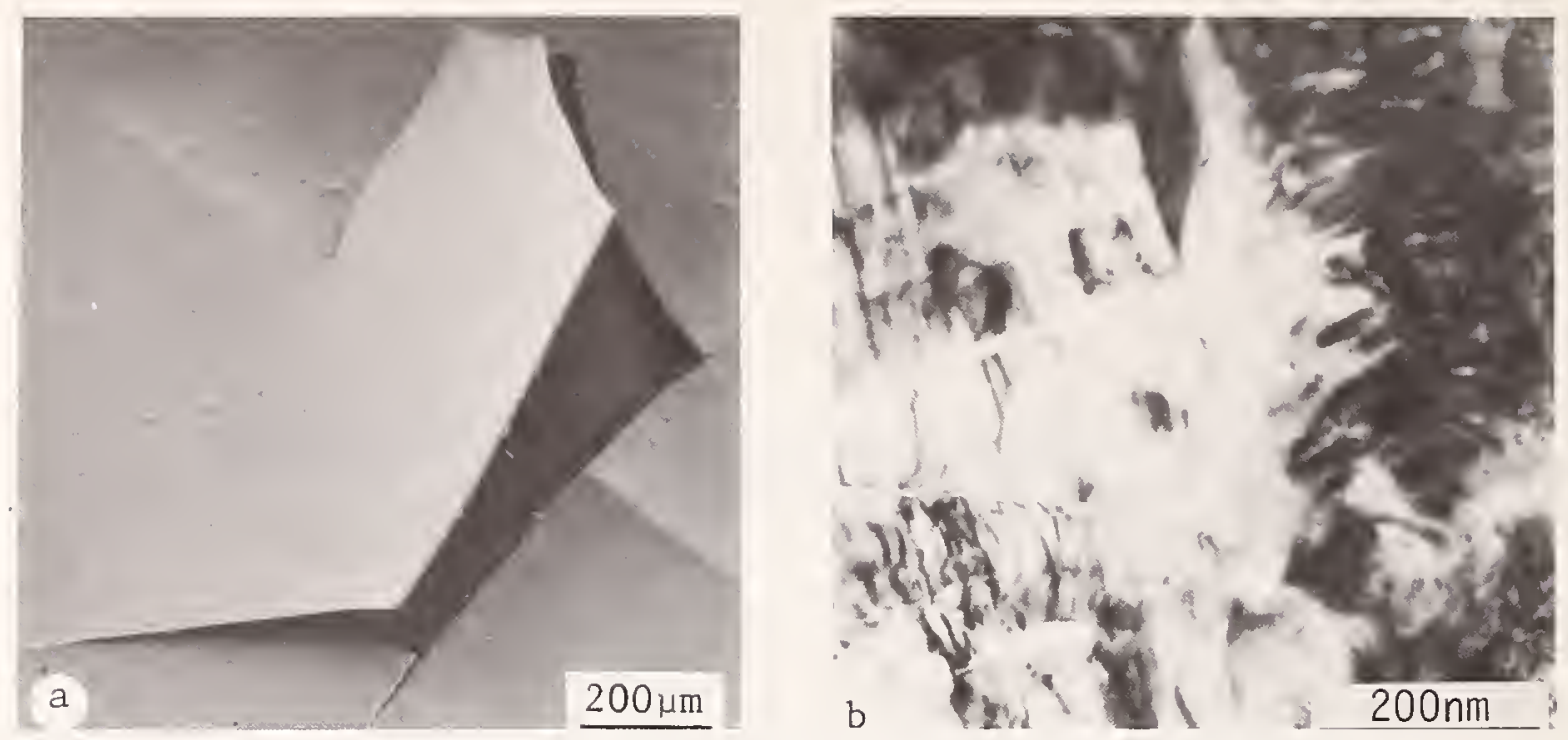

Fig. 1 Grinding damage (a) scanning electron micrograph of a thin foil specimen which curled-up as a result of strain on one ground side. (b) TEM showing sub-surface damage.

analyses of as-received and of tested specimens have previously been limited in scope [1-3]. Without such analyses it will become increasingly difficult to tailor silicon nitride materials to the desired applications in turbine engines. In the present paper we identify some microstructural features characteristic of deformation, of fracture and of oxidation in specimens made from magnesia-doped compositions.

\section{Materials and Procedures}

Samples were made from hot-pressed silicon nitride (HPSN) billets which had a hot pressing additive of $\mathrm{MgO}$ or of an $\mathrm{MgO}$ precursor. Spectrographic analysis by the manufacturer showed typical impurities as: Al $0.2 \mathrm{w} / \mathrm{o}, \mathrm{Ca} 0.05 \mathrm{w} / \mathrm{o}, \mathrm{Fe} 0.40-0.64 \mathrm{w} / \mathrm{o}$ $\mathrm{Mg} 0.70-0.74 \mathrm{w} / \mathrm{o}, \mathrm{W} 2.6-2.7 \mathrm{w} / \mathrm{o}$.

Microstructural examination was carried out on specimens from: (a) 4-pt. bend bars tested at $1400^{\circ} \mathrm{C}$; (b) double torsion specimens [4] tested at $1400^{\circ} \mathrm{C}$; (c) bulk and thin foil samples oxidized by heating in air at $1000^{\circ} \mathrm{C}, 1200^{\circ} \mathrm{C}$ and $1400^{\circ} \mathrm{C}$; and (d) samples ground with 400 mesh SiC abrasives. Thin foils for transmission electron microscopy (TEM) were prepared by the ion sputtering technique [5]. In making foils to show the grinding damage it was necessary to sputter away $\sim 1 / 2-1 \mu \mathrm{m}$ from the ground surface to keep the foil from curling-up as shown in Fig. $1 \mathrm{~b}$. Double torsion specimens were sectioned parallel to the tension surfaces and $3 \mathrm{~mm}$ disks for thin foils were cut out along the crack length. 

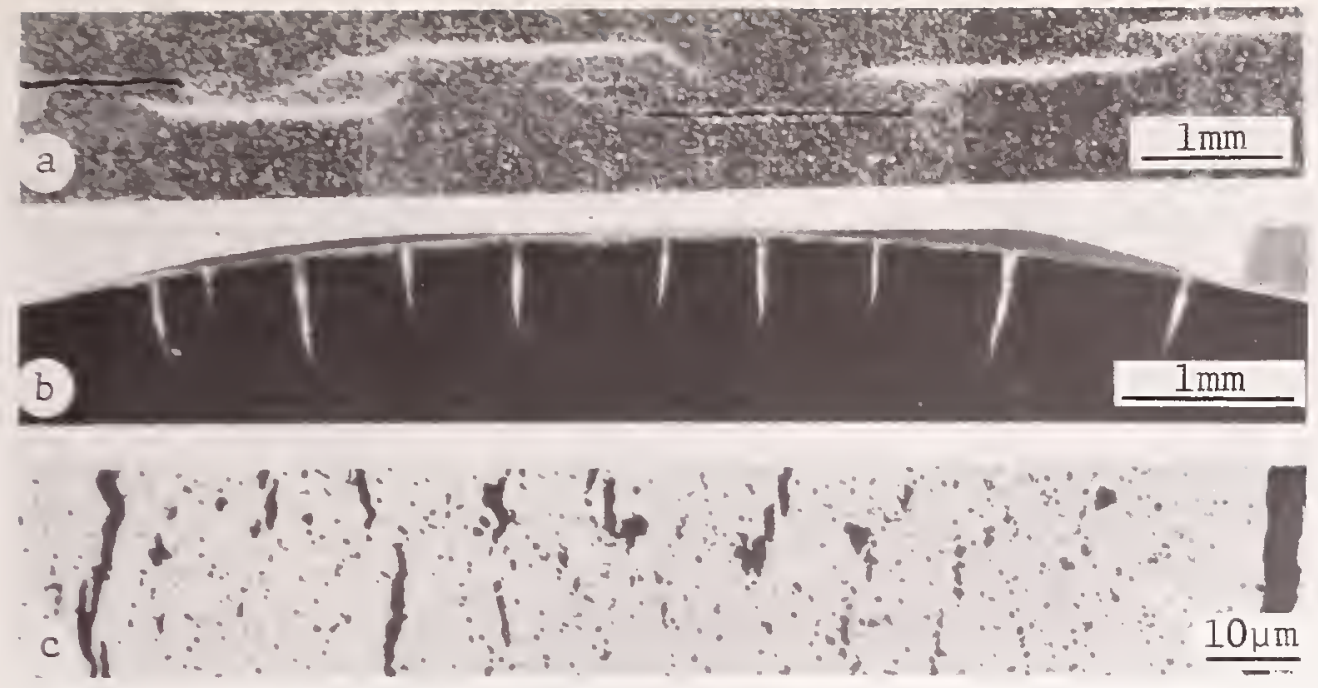

Fig. 2 Light micrographs of cracks in specimens deformed at $1400^{\circ} \mathrm{C}$ (a) tension surface of double-torsion specimen, (b) tension side of 4-pt. bend bar, (c) area between edge cracks in (b).

3. Results

3.1 Surface Damage

Test specimens usually are ground to produce uniformly flat surfaces. Cracks and chips which occur during the grinding process can penetrate several tens of micrometers. Such surface cracks become the strength limiting flaws of fracture mechanics theories.

The damage found near a ground surface is shown in Fig. 1b. The dislocation density is high and the strain contrast in the image reduced the resolution. The micrograph shows, however, the dislocations and cracks that constitute some of the near surface grinding damage.

\subsection{Slow Crack Growth}

At temperatures above $1200^{\circ} \mathrm{C}$ and at low strain rates magnesiadoped silicon nitride exhibits slow crack growth [4,6] and samples deform plastically at relatively low stress.

Specimens which exhibited slow crack growth during crack propagation experiments of $1400^{\circ} \mathrm{C}$ were examined by light and electron microscopy. Cracks which had formed in the tension side of specimens were filled partially with oxide; and, therefore were easily visible. The segmented primary crack shown in Fig. 2 a demonstrates the characteristic fracture pattern of slow crack growth in HPSN.

Cracks were produced along the tension side of a 4-pt. bend bar which was tested at $1400^{\circ} \mathrm{C}$. When the surface oxide was polished away the deep cracks shown in Fig. $2 b$ were seen along the specimen edge; however, near the center of the bar cracks penetrated only a few tenths of a mm. Short crack segments which occurred between the deep edge cracks are shown in Fig. 2c. These observations suggest that the crack growth was influenced by edge effects and by surface oxidation. 

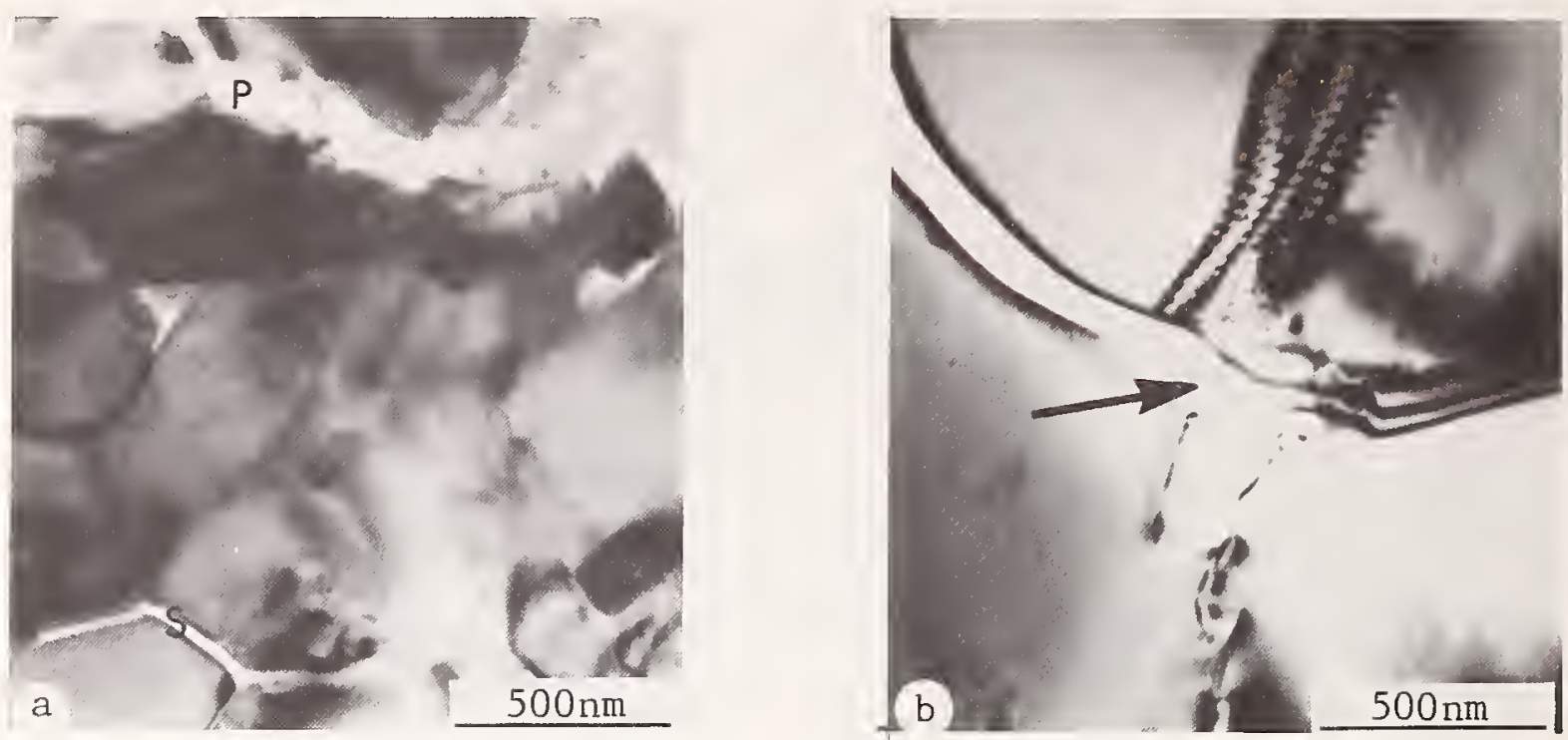

Fig. 3 Electron micrographs of cracks produced in double-torsion specimens tested at $1400^{\circ} \mathrm{C}$, (a) primary (P) and secondary cracks (S), (b) dislocation arrays at the tip of a secondary crack.

In double-torsion specimens, electron microscopy showed that cracks occurred along grain boundaries. The primary crack and the secondary cracks were oriented approximately paralle1 to each other and were separated by one or more grains. An example of this configuration is shown in Fig. 3a. Figure 3b shows a crack tip which is several grain diameters away from the primary crack. The crack is several grains long and dislocations are seen emanating from the crack tip into the two adjacent grains.

Because of severe cracking along the tension surface of bend specimens thin foil specimens were made from regions several micrometers beneath the oxide layer. These samples showed primarily the microstructure similar to that seen in double-torsion specimens, namely intergranular fracture, and dislocation arrays near grain boundaries.

Grains on the compression side of the bent bars had extensive arrays of bubbles, (B), dislocation arrays, (P) associated with grain boundaries and in sub-grain boundaries. The pictures in Fig. 4a, b show typical areas in these samples.

\subsection{Oxidation}

Silicon nitride oxidizes readily in air above $1000^{\circ} \mathrm{C}$, however the effects of the oxide on mechanical properties has not been established. The thickness and the structure of the oxide layer are related to the temperature and time of heating. The $x-r a y$ diffraction patterns obtained from oxidized specimen surfaces showed that $\beta$-cristobalite was present in samples oxidized at $1000^{\circ} \mathrm{C}$, $1200^{\circ} \mathrm{C}$ and $1400^{\circ} \mathrm{C}$ that enstatite $\left(\mathrm{MgSiO}_{3}\right)$ and possibly pigeonite $\left(\mathrm{Mg}_{2} \mathrm{Fe}_{2} \mathrm{Ca}\right)$ [ $\mathrm{Si}_{2} \mathrm{O}_{6}$ ] were present in samples heated at $1400^{\circ} \mathrm{C}$. When the oxides were examined by electron microscopy, two amorphous phases were found in addition to these crystalline phases. 

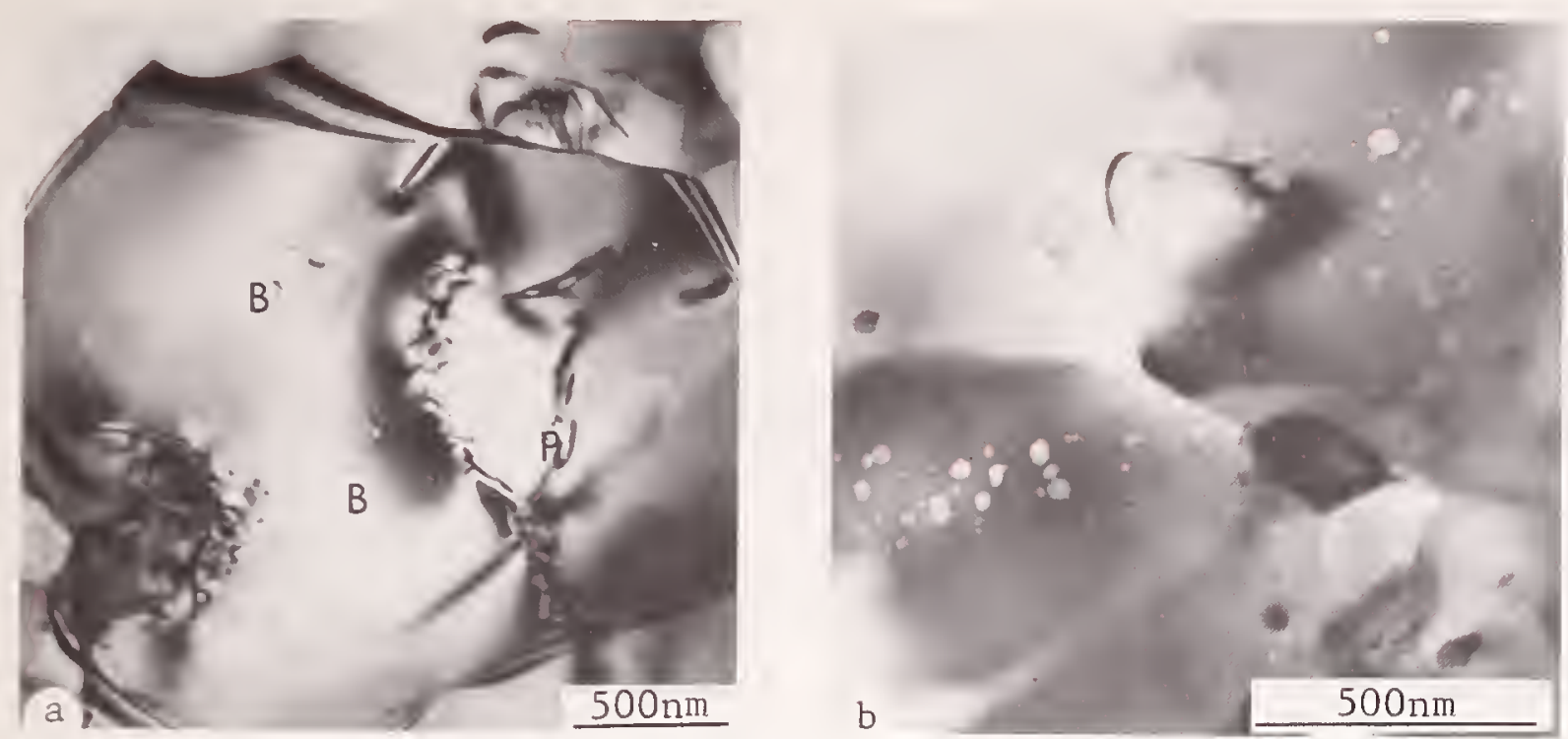

Fig. 4 Compression side of a bent sample showing (a) Bubbles, and dislocation arrays within a grain, (b) Extensive array of voids.

A cross section of the oxide formed on a specimen heated 96 hrs at $1400^{\circ} \mathrm{C}$ is shown in Fig. 5a. The oxide is polycrystalline and polyphase and has many pores and cracks. This specimen was heated cyclically and the oxide appeared to have melted during this heat treatment.

Electron microscopy on the sample in Fig. 5a showed that the oxide nearest the $\mathrm{Si}_{3} \mathrm{~N}_{4}$ matrix was $\mathrm{Si}_{2} \mathrm{~N}_{2} \mathrm{O}$. This phase was distinguished also by light microscopy, and, from the light microscopy examination it appeared that the oxide formed nodules which grew to cover the surface. Large grains of silicon oxy-nitride were found in the thin sections, and these grains were heavily faulted as shown in Fig. $5 \mathrm{~b}$.

In the layer adjacent to the silicon oxynitride, enstatite and cristobalite were found. The electron micrograph in Fig. 6a shows an enstatite grain with its characteristic faulting and a partially vitrified cristobalite grain.

Cristobalite was found in all the oxidized specimens. In thin foils which were oxidized at $1000^{\circ} \mathrm{C}$ and at $1200^{\circ} \mathrm{C}$, $\beta$-cristobalite occurred as grains within a glassy matrix. However, under the influence of the electron beam, the $\beta$-cristobalite decomposed first to $\alpha$-cristobalite an amorphous phase. The grain shape did not change during this vitrification. The vitrification occurred in less than two minutes and Fig. $6 \mathrm{~b}$ shows both transformed and nontransformed grains. The diffraction pattern taken from the vitrified $\beta$-cristobalite was used to differentiate the amorphous silica phase from the other amorphous phase. It is possible that the second amorphous phase is a magnesium silicate glass. Cristobalite and various pyroxene phases can occur by devitrification of a magnesium silicate glass at $1400^{\circ} \mathrm{C}$ as well as during cooling to room temperature. 

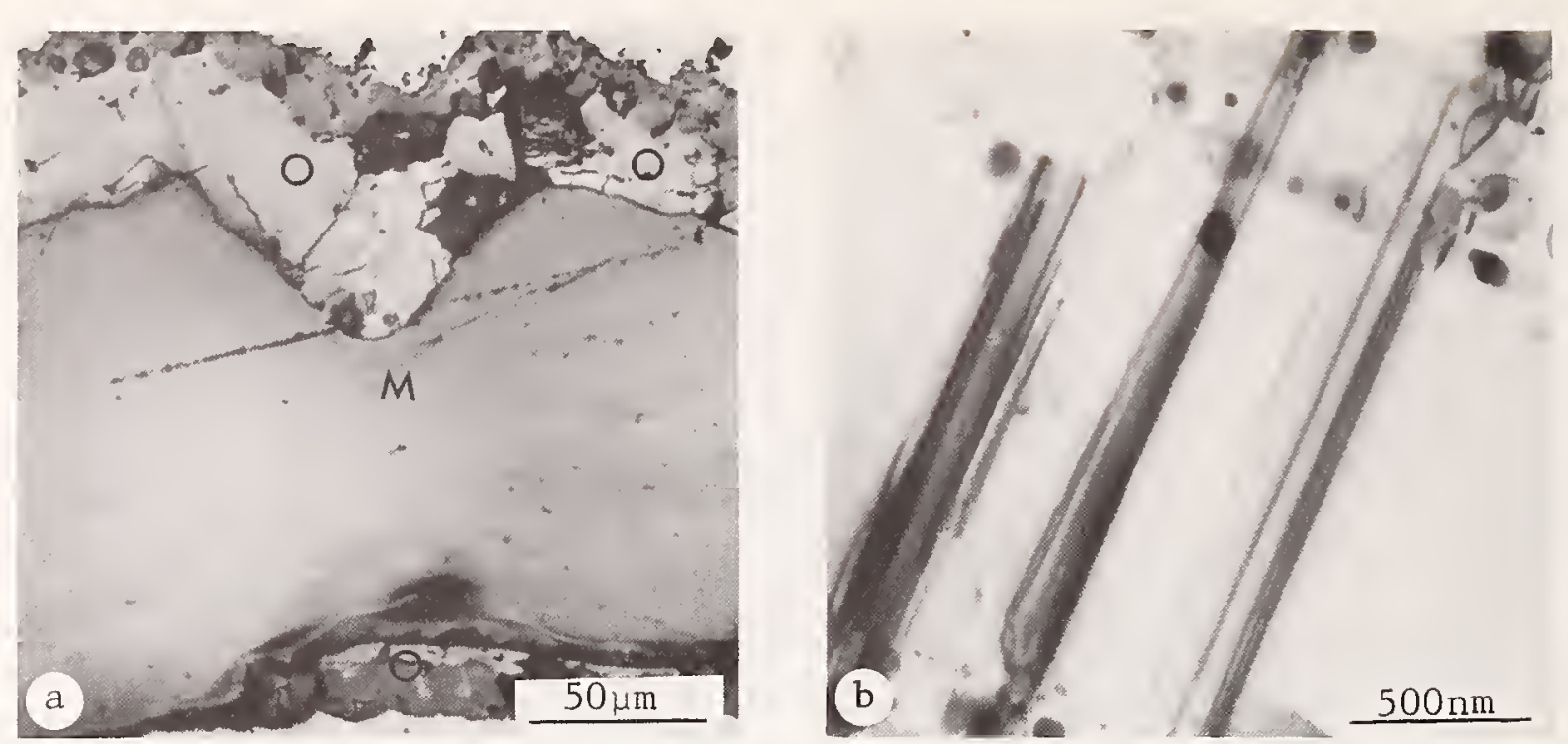

Fig. 5 Oxide produced at $1400^{\circ} \mathrm{C}$, (a) light micrograph showing oxide (0) on both surfaces of $\mathrm{Si}_{3} \mathrm{~N}_{4}$ specimen (M), (b) $\mathrm{Si}_{2} \mathrm{~N}_{2} \mathrm{O}$ grain.

Enstatite is one phase in the pyroxene group of calcium, magnesium iron silicates which form an impressive array of mineral structures. These structures are difficult to identify from electron diffraction patterns alone. The $\mathrm{Ca}, \mathrm{Mg}$ and $\mathrm{Fe}$ are the major impurities in the magnesia-doped silicon nitride and their presence in an oxide layer indicates that considerable diffusion occurred during oxidation.

4. Discussion and Conclusions

\subsection{Microstructural Factors Affecting Strength}

Other investigators attributed deformation of magnesia-doped silicon nitride to grain boundary sliding from a glass binder between grains $[1,6]$. However this glass phase was not evident in the samples discussed in this paper. Cracks did propagate primarily along grain boundaries indicating that grain boundaries presented easy fracture paths. It is possible that impurities can segregate near grain boundaries and can weaken their bonding without forming a distinct glass phase.

The electron microscopy results show that slow crack growth, which occurs at low strain rates, is characterized by branching of grain boundary cracks and by localized plastic deformation at crack tips and along grain boundaries. Oxide formation during the deformation may influence the crack growth.

The surface oxide can have an initial strengthening effect by filling up and healing flaws produced during machining. However, the oxide forms preferentially at fresh fracture interfaces and penetrates deeply into the matrix during continued deformation. 

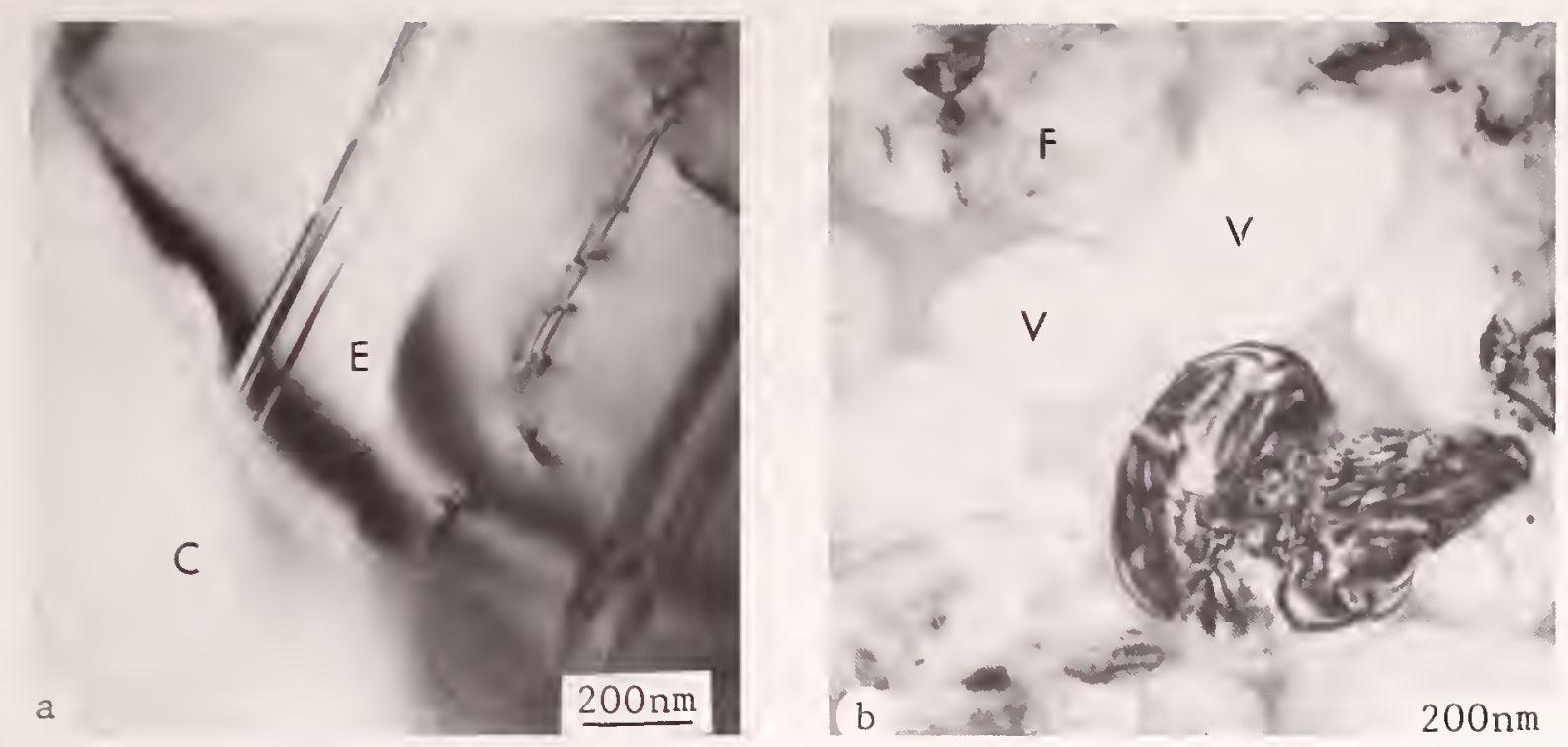

Fig. 6 Phases found in oxide produced by heating at $1400^{\circ} \mathrm{C}$ (a) enstatite, $\mathrm{MgSiO}_{3}$ (E) and $\beta$-cristobalite grains in the mid-oxide layer. (b) B-cristobalite formed on a thin foil oxidized $1 \mathrm{hr}$ at $1200^{\circ} \mathrm{C}$; area shows faulted grains and some vitrified grains.

This sub-surface oxide penetration can weaken the structure during prolonged stressing at elevated temperatures. Changes in oxide composition from silica to magnesium silicate decrease the viscosity and the melting point and thus modify the oxide behavior at temperature.

Consideration of the microstructure suggests that the effects of the oxide growth and of the structural inhomogenities which contribute to uneven thermal stress distribution should be accounted for in the development of deformation models for HPSN. It will be useful to compare the microstructures of silicon nitride compacts having different sintering additives and to examine specimens after deformation in inert as well as in oxidizing atmospheres.

Acknowledgments

This work was supported by the USAF under grant no. F33615-76-F-6752. We thank Mr. L. Russell for performing mechanical tests, and Mr. G. Garrett for printing the photographs.

References

1. R. Kossowsky, "The Microstructure of Hot-Pressed Silicon Nitride" J. Mat1. Sci. 8 1603-1615 (1973).

2. P. Drew and M. H. Lewis, "The Microstructure of Silicon Nitride Ceramics During Hot-Pressing Transformation" J. Mat1. Sci. 9 261-269 (1974).

3. N. J. Tighe, "Microstructure of Oxidized Silicon Nitride" Proc. EMSA 420-471 (1974). 
4. A. G. Evans and S. M. Wiederhorn, "Crack Propagation and Failure Prediction in Silicon Nitride at Elevated Temperatures" J. Matl. Sci. ㅇ, 270-278 (1974).

5. N. J. Tighe, Experimental Techniques in Electron Microscopy in Mineralogy, (ed.) H. R.-Wenk, Springer Verlag, Berlin 1976.

6. F. F. Lange, "High-Temperature Strength Behavior of Hot-Pressed $\mathrm{Si}_{3} \mathrm{~N}_{4}$ : Evidence for Sub-Critical Crack Growth" J. Am. Ceram. Soc. $57,84-89$ (1974). 


\begin{tabular}{|c|c|c|c|}
\hline $\begin{array}{l}\text { U.S. DEPT. OF COMM. } \\
\text { BIBLIOGRAPHIC DATA } \\
\text { SHEET }\end{array}$ & $\begin{array}{l}\text { 1. PUBLICATION OR REPORT NO. } \\
\text { NBSIR } 76-1153\end{array}$ & $\begin{array}{l}\text { 2. Gov't Accession } \\
\text { No. }\end{array}$ & 3. Recipient's Accession No. \\
\hline \multirow{2}{*}{\multicolumn{3}{|c|}{$\begin{array}{l}\text { 4. TITLE AND SUITITLE } \\
\text { Microstructural Aspects of Deformation and Oxidation of } \\
\text { Magnesia Doped Silicon Nitride }\end{array}$}} & $\begin{array}{l}\text { 5. Publication Date } \\
\text { September } 1976\end{array}$ \\
\hline & & & 6. Performing Organization Code \\
\hline \multirow{2}{*}{\multicolumn{3}{|c|}{$\begin{array}{l}\text { 7. AUTHOR(S) } \\
\text { N. J. Tighe } \\
\text { 9. PERFORMING ORGANIZATION NAME AND ADDRESS } \\
\text { NATIONAL BUREAU OF STANDARDS } \\
\text { DEPARTMENT OF COMMERCE } \\
\text { WASHINGTON, D.C. } 20234\end{array}$}} & $\begin{array}{l}\text { 8. Performing Organ. Report No. } \\
\text { NBSIR } 76-1153\end{array}$ \\
\hline & & & $\begin{array}{l}\text { 10. Project/Task/Work Unit No. } \\
3130459 \\
\text { 11. Contract/Grant No. } \\
\text { F33615-76-F-6752 }\end{array}$ \\
\hline \multicolumn{3}{|c|}{$\begin{array}{l}\text { 12. Sponsoring Organization Name and Complete Address (Street, City, State, ZIP) } \\
\text { United States Air Force } \\
\text { Air Force Systems Command } \\
\text { Aeronautical Systems Division } \\
\text { Wright Patterson AFB, Ohio } 45433\end{array}$} & $\begin{array}{l}\text { 13. Type of Report \& Period } \\
\text { Covered } \\
\text { Interim Jul/Sept } 1976 \\
\text { 14. Sponsoring Agency Code }\end{array}$ \\
\hline
\end{tabular}

15. SUPPLEMENTARY NOTES

16. ABSTRACT (A 200-word or less factual summary of most significant information. If document includes a significant bibliography or literature survey, mention it here.)

The microstructural changes that occurred in magnesia-doped silicon nitride as a result of slow crack growth, plastic deformation and oxidation were studied by transmission electron microscopy. Specimens which exhibited slow crack growth showed extensive crack branching along the fracture path and ahead of the primary crack tip. These primary and secondary cracks followed intergranular paths. In samples which were deformed by bending at $1400^{\circ} \mathrm{C}$, dislocation arrays were found as well as intergranular cracks and voids. Silicon nitride oxidized during heating in air at $1400^{\circ} \mathrm{C}$ and enstatite and cristobalite were present in the oxide layer. At lower oxidation temperatures, crystalline and amorphous silica formed a semiprotective layer on the silicon nitride surfaces.

17. KEY WORDS (six to twelve entries; alphabetical order; capitalize only the first letter of the first key word unless a proper name; separated by semicolons)

Silicon nitride, electron microscopy, deformation, oxidation, microstructure, slow crack growth enstatite, cristobalite

18. AVAILABILITY

X Unlimited

For Official Distribution. Do Not Release to NTIS

Order From Sup. of Doc., U.S. Government Printing Office

Washington, D.C. 20402, SD Cat. No.C13

$\mathrm{X}$ Order From National Technical Information Service (NTIS) Springfield, Virginia 22151
19. SECURITY CLASS (THIS REPURT)

UNCL ASSIF IED

20. SECURITY CLASS (THIS PAGE)

UNCLASSIFIED
21. NO. OF PAGES

10

22. Price

$\$ 3.50$ 
